\title{
Towards the systematics of the subterranean amphipod genus Niphargus (Crustacea: Amphipoda: Niphargidae) of Transcaucasia: new records of $N$. inermis and $N$. iniocbus in Abkhazia
}

\section{К систематике подземных амфипод рода Niphargus (Crustacea: Amphipoda: Niphargidae) Закавказья: новая находка N. inermis \\ и N. iniochus в Абхазии}

\author{
Dmitry A. Sidorov \\ A.A. Сидоров \\ Institute of Biology and Soil Science FEBRAS, 100-let Vladivostoku Av. 159, Vladivostok 690022, Russia. E-mail: \\ biospeorossica@gmail.com \\ Биолого-почвенный институт ДВО РАН, пр. 100-лет Владивостоку 159, Владивосток, 690022, Россия.
}

KEY WORDS: Amphipoda, Niphargus, Abkhazia, Western Caucasus, new records, mt-cox1.

КЛЮЧЕВЫЕ СЛОВА: Amphipoda, Niphargus, Абхазия, Западный Кавказ, новые находки, mt-cox1.

ABSTRACT. The subterranean amphipod Niphragus inermis Birstein, 1940 and N. iniochus Birstein, 1941 (Crustacea: Niphargidae) are newly reported from the high-mountain limestone cave at Arabika karstic massif and from the Nizhne-Shakuranskaya cave near Tsabal (Abkhazia). Based on the recently collected materials additional morphological features are described and figured in this paper.

РЕЗЮМЕ. Сообщается о новых находках подземных бокоплавов Niphragus inermis Birstein, 1940 и N. iniochus Birstein, 1941 (Crustacea: Niphargidae) в высокогорной известняковой пещере карстового массива Арабика и в Нижне-Шакуранской пещере у пос. Цабал (Абхазия). На основе новых материалов описаны и обрисованы дополнительные морфологические признаки для обоих видов.

\section{Introduction}

The genus Niphargus Schiödte, 1849 is distributed mostly in karstic areas of the Europe West of Black Sea where it is represented by about 300 described species, whilst in the Caucasus about 25 species are known. Moreover, the majority of the Caucasian species of Niphargus are briefly described that makes it impossible to figure out the clear relationship between them. The subterranean niphargid amphipods in Abkhazia have been studied by Birstein [1940, 1941, 1952] and Derzhavin [1945]. These authors reported on 7 Niphargus species. Much later, Skalski [1980] reported on $N$. ablaskiri Birstein, 1940 from Novoafonskaya cave discussing its systematic position. A summaries of Zaitsev [1948] and Karaman [2012] are also useful as a historical overview of Niphargus species inhabiting Caucasus.
The aim of our study was to identify the invertebrate specimens collected in two limestone Abkhazian caves.

\section{Material and methods}

TAXONOMIC SAMPLING. A small collection of invertebrates from Troika cave of Abkhazia was identified. Since the original description of $N$. inermis is rather poor and this species is difficult to identify, the amphipod collection from Nizhne-Shakuranskaya cave that is a locus typicus for $N$. inermis was further investigated and compared. The second species $N$. iniochus was also detected in sample from the Nizhne-Shakuranskaya cave together with $N$. inermis and so we decided to bring it re-description and comparison with congeners.

Studied localities (Fig. 1, black dots):

- Abkhazia, Gagra Mountain Range, Arabika massif, speleological district "Treugol'nik", Troika cave (cave 003), (approx., 43.383333, 40.366667), -30 m depth, cave pool, 27 Aug 2012, coll. E. Golubnichaya.

Niphargus inermis Birstein, 1940

Haplotaxis gordioides (Hartmann, 1821)

Zenkevitchia sp. A.

- Abkhazia, Gulripshi district, near Tsebelda (Tsabal), Nizhne-Shakuranskaya cave (43.029933, 41.3339), cave river, 13 Apr and 30 Jan 2012, coll. D. Palatov.

Niphargus inermis Birstein, 1940

Niphargus iniochus Birstein, 1941

Zenkevitchia admirabilis Birstein, 1941

MORPHOLOGY. A complete dissection was made of all pertinent morphological structures of specimens in the type series and placed in permanent preparations, using polyvinyl lactophenol (PVL) and methyl- 


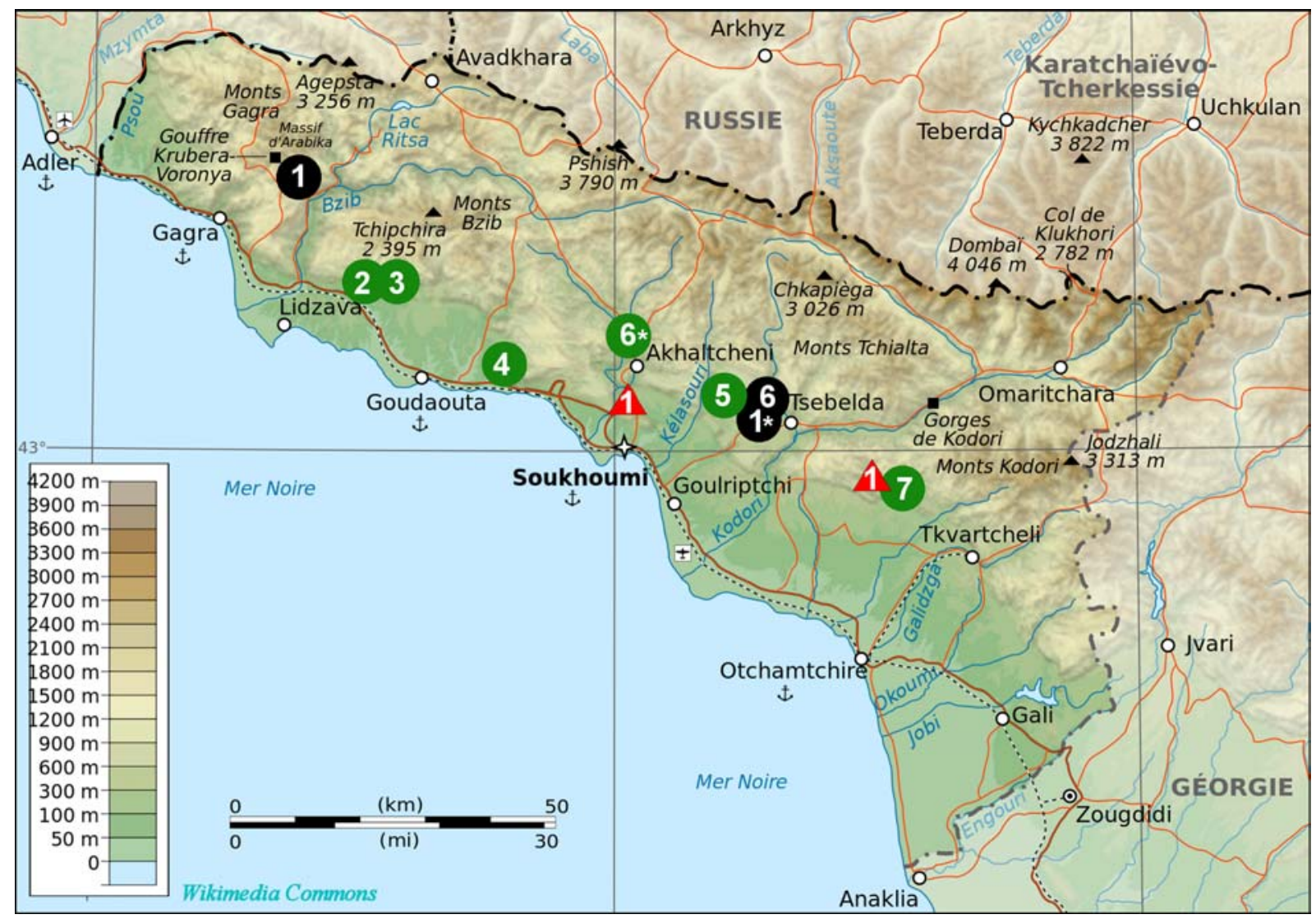

Fig. 1. Map indicating geographic distribution of Niphargus species in Abkhazia. $1-N$. inermis Birstein, 1940; $2-N$. eugeniae Derzhavin, 1945; $3-N$. otharicus Birstein, 1952; $4-N$. ablaskiri Birstein, $1940 ;{ }^{1} 5-N$. derzhavini Birstein, $1952 ; 6-N$. iniochus Birstein, 1941; $7-N$. magnus Birstein, 1940. The asterisk (*) indicates the locus typicus; (red triangle) location of caves Mikhailovskaja and "Golova Atapa" (see explanation in text).

Рис. 1. Карта отражающая географическое распространение видов Niphargus в Абхазии. $1-N$. inermis Birstein, 1940; $2-N$. eugeniae Derzhavin, 1945; $3-N$. otharicus Birstein, 1952; $4-N$. ablaskiri Birstein, 1940; ${ }^{15}-N$. derzhavini Birstein, $1952 ; 6-N$. iniochus Birstein, 1941; 7 - N. magnus Birstein, 1940. Звездочка (*) указывает типовое местонахождение; (красный треугольник) местоположение пещер Михайловская и "Голова Атапа" (см.: объяснение в тексте).

' Birstein [1952] erroneously indicates Olginskaya in Gagra region; Barijal — river and settlement near Tsebelda in Gulripshi district (43.030753, 41.2352943), in 1867 renamed to Olginskoye, in 1943 renamed to Oktomberi (Georgian), in 1996 restored the old name Barijal (see Voronov 1969: 88).

ene blue staining solution. Prior to dissection, body length was recorded by holding the specimen straight and measuring the distance along the dorsal side of the body from the base of the first antennae to the base of the telson. A Lomo MBS-9 stereomicroscope with a scaled micrometer eyepiece was used to make the measurements and appendages were drawn using a Carl Zeiss NU-2 compound microscope equipped with a drawing device as modified by Gorodkov [1961]. A lens adapter LSN-30D by Zarf Enterprises for Nikon CoolPix 995 was used for photomicrography of the body.

The term "defining angle" of the gnathopod propodi refers to the angle formed at the end of the palm and beginning of the posterior margin or the point at which the tip of the dactylus closes on the propodus [Holsinger, 1974]. The nomenclature for setal patterns on article 3 of the mandibular palp and gnathopods $1-2$ propodi follows the standard introduced by Karaman [1969].
The following description is based on the material are examined and deposited in the Zoological Museum of the Far East Federal University, Vladivostok (FEFU).

DNA EXTRACTION, AMPLIFICATION, SEQUENCING AND ANALYSIS. Total DNA was extracted from the muscle tissue with a DNeasy Blood \& Tissue kit (QIAGEN GmbH, Hilden, Germany) according to the manufacturer's guideline. The coxl gene fragment was amplified using the universal primers HCO2198 and LCO1490 [Folmer et al., 1994]. The annealing temperature was set to $40^{\circ} \mathrm{C}$ for $20 \mathrm{sec}$. The PCR products were sequenced directly using the same primers and a BigDye terminator v. 3.1 sequencing kit (Applied Biosystems, USA). Sequences were analyzed on an ABI 3130 genetic analyzer (Applied Biosystems, USA), assembled with the Staden Package v. 1.4 [Bonfield et al., 1995] and deposited into GenBank (KJ415376). 


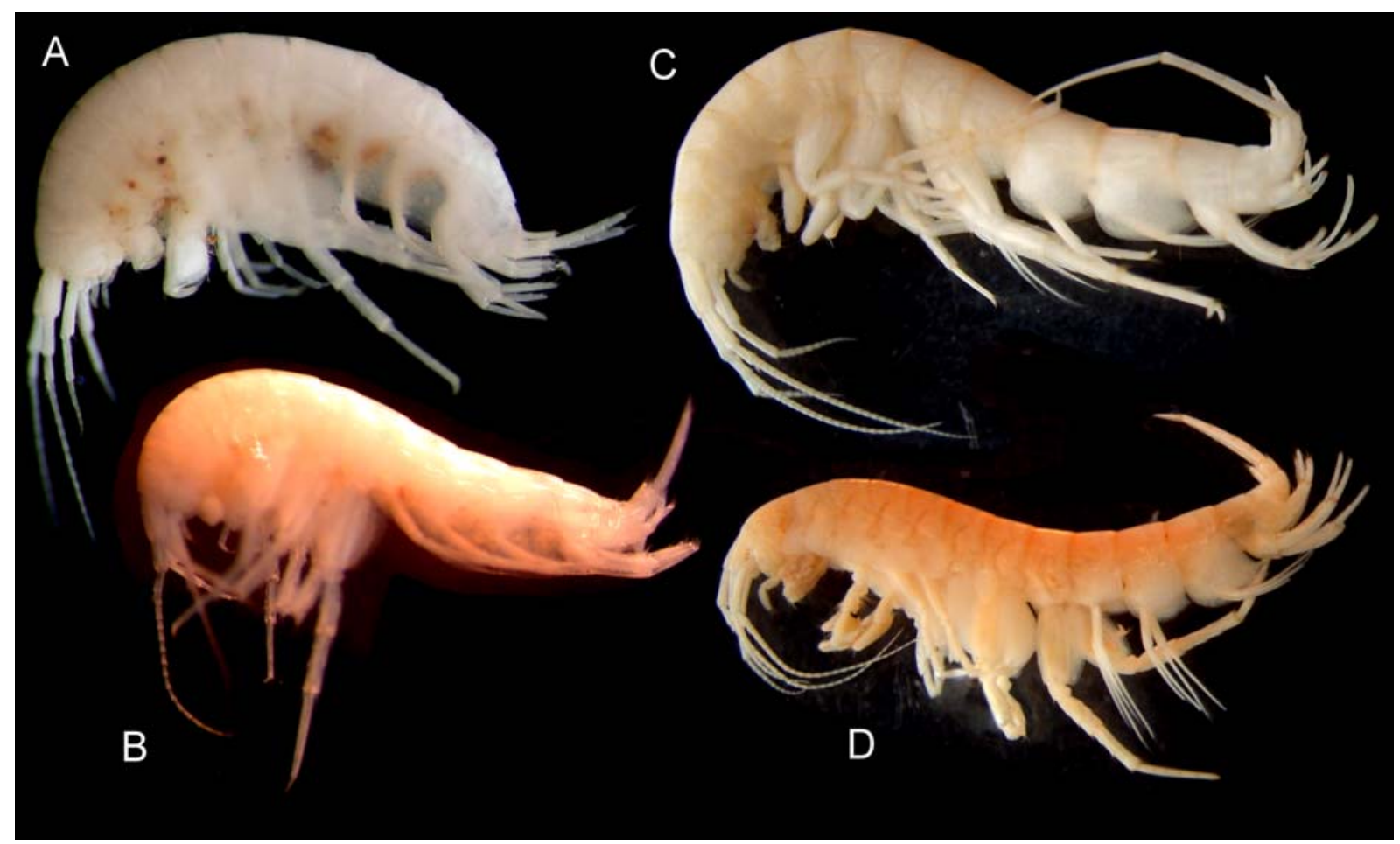

Fig. 2. (A) Niphargus inermis Birstein, 1940, from left side, female, $4.8 \mathrm{~mm}, \mathrm{X} 40561 / \mathrm{Cr}-1478$-FEFU, Troika cave; (B) N. inermis Birstein, 1940, from left side, female, $6.2 \mathrm{~mm}, 110 / 1 \mathrm{sd}-\mathrm{IBSS}$, Nizhne-Shakuranskaya cave; (C) N. iniochus Birstein, 1941, from left side, male, $17.0 \mathrm{~mm}$, X40561/Cr-1479-FEFU, Nizhne-Shakuranskaya cave; (D) N. iniochus Birstein, 1941, from left side, female, $12.0 \mathrm{~mm}$, X40561/Cr-1479-FEFU, Nizhne-Shakuranskaya cave.

Рис. 2. (А) Niphargus inermis Birstein, 1940, слева, самка, 4,8 мм, X40561/Cr-1478-FEFU, пещ. Тройка; (В) N. inermis Birstein, 1940, слева, самка, 6,2 мм, 110/1sd-IBSS, Нижне-Шакуранская пещ.; (C) N. iniochus Birstein, 1941, слева, самец, 17,0 мм, X40561/ Cr-1479-FEFU, Нижне-Шакуранская пещ.; (D) N. iniochus Birstein, 1941, слева, самка, 12,0 мм, X40561/Cr-1479-FEFU, НижнеШакуранская пещ.

\section{Taxonomic part}

Order Amphipoda Latreille, 1816

Family Niphargidae Bousfield, 1977

Genus Niphargus Schiödte, 1849

Niphargus Schiödte, 1849: 26, tab. 3, figs. 1-11 (orig. descrip.). - Barnard, Barnard, 1983: 688 (full synonymy).

TYPE SPECIES. Niphargus stygius (Schiödte), 1847 = Gammarus stygius (Schiödte), 1847 [locus typicus, cave-lakes in Postojnska Jama cave, Slovenia]

REMARKS. The BLAST search (blast.ncbi. nlm.nih.gov) revealed $80-81 \%$ identity ( $97 \%$ cover) of our sequence GenBank acc. KJ415376 to numerous isolates of Niphargus ictus G. Karaman, 1985. Phylogenetic analyses based on all non-redundant Niphargus sequences (18 sequences out of about 300 recognized species) resolved a sister relationship (64-77\% bootstrap support; result not shown) between $N$. inermis from the Troika cave and $N$. aquilex from the North German Plain (JF420841) and UK (JF420842). Since no sequences of any other Niphargus species from Caucasus or neighboring area are currently available therefore no conclusion on affinity of $N$. inermis could be drawn based on this very limited data set.
Niphargus inermis Birstein, 1940

Figs 2A,B, 3-36.

Niphargus ablaskiri inermis Birstein, 1940: 50, fig. 3 (orig. descrip.). - Birstein, 1952: 36. —-Skalski, 1980: 38. — Barnard, Barnard, 1983: 689 .

Niphargus inermis: Straškraba, 1972: 85 (“carpathicus" group). — Karaman, 2012: 75.

DIAGNOSIS (both sexes). Moderately slender, small-sized specimens (sexual dimorphism indistinct). Antenna 1 short, reaching 40 to $45 \%$ length of body; antenna 2 relatively slender, reaching 60 to $65 \%$ length of antenna 1. Maxilla 1 inner plate with one plumose seta, outer plate with 7 spines (most of them with 1 lateral tooth). Mandibular palp article 3 with 1 A group of 3-4 setae, 3-4 C single setae, 7-14 D single setae, 4-5 E single setae. Gnathopods 1-2 relatively small, with propodus not larger than corresponding coxa; defining angles of both gnathopods with one strong corner S-spine accompanied laterally by 2 serrate L-spines on outer side, single supporting R-spine on inner face; dactyli along outer margin with 1 median seta, nails relatively long; inner margin of dactyli of pereopods 3 and 4 naked (without any spine or seta near basis of the nail); dactyli of pereopods 5-7 with 1 seta at inner margin near basis of the nail. Urosomites 1-2 with 


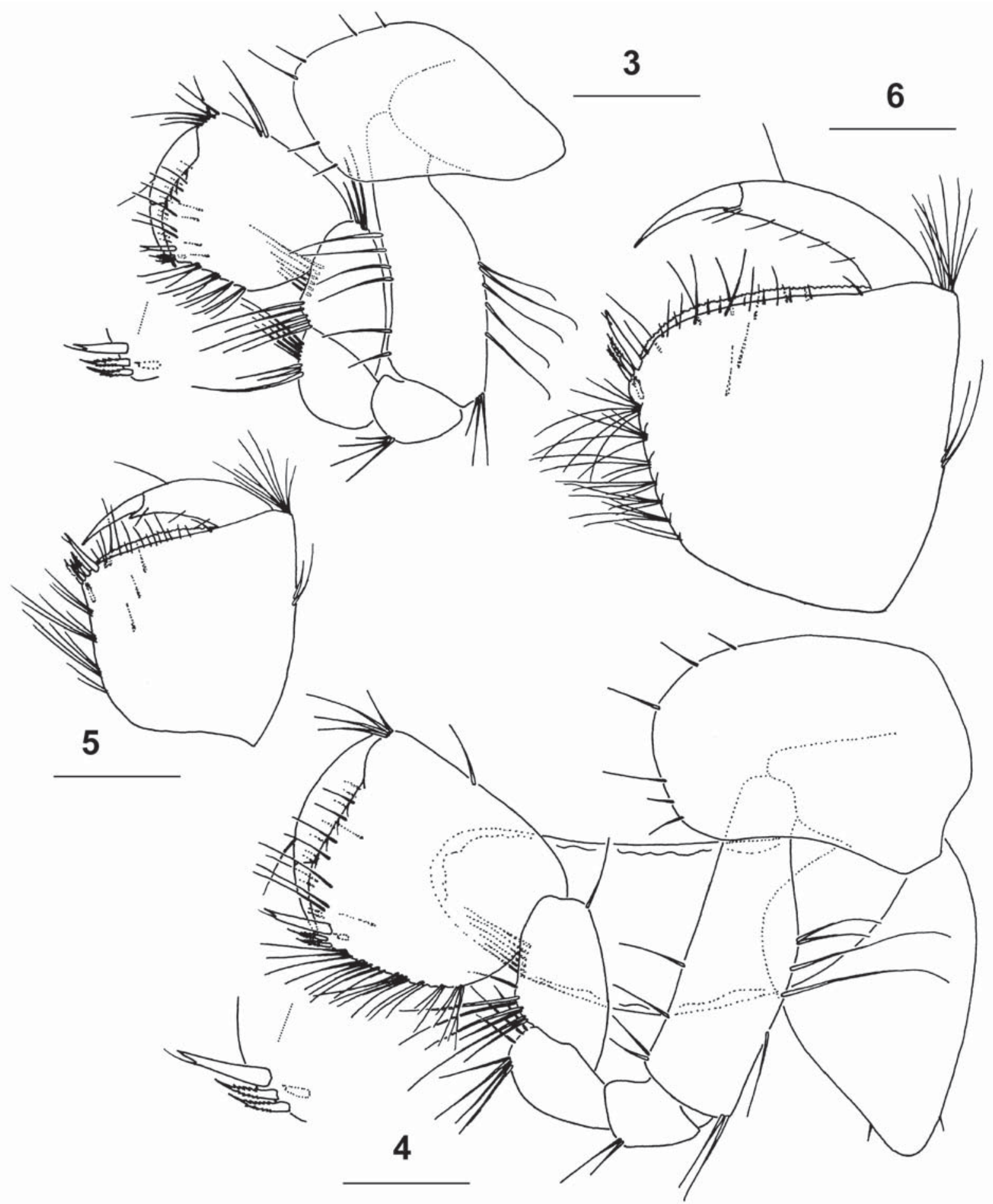

Figs 3-6. Niphargus inermis Birstein, 1940, female, 4.8 mm, X40561/Cr-1478-FEFU, Troika cave: (3) gnathopod 1; (4) gnathopod 2. Female, $5.5 \mathrm{~mm}$, X40561/Cr-1478-FEFU: (5) gnathopod 1 propodus; (6) gnathopod 2 propodus. Scale bars $0.2 \mathrm{~mm}$.

Рис. 3-6. Niphargus inermis Birstein, 1940, самка, 4,8 мм, X40561/Cr-1478-FEFU, пещ. Тройка: (3) гнатопод 1; (4) гнатопод 2. Самка, 5,5 мм, X40561/Cr-1478-FEFU: (5) проподус гнатопода 1; (6) проподус гнатопода 2. Линейки 0,2 мм.

dorsolateral spines. Pleopods $1-3$ with 4 retinacula each. Uropod 1 rami almost equal (inner ramus scarcely longer than outer one); uropod 3 short; telson with distal and lateral spines, facial spines absent. Coxal gills 2-6 large, sacci-forme. Oostegites 2-5 very large, setose with long stiff setae. Body length $4.8-11.0 \mathrm{~mm}$ (females), 6.2 (males).

MATERIAL EXAMINED. 2 females, $4.8 \mathrm{~mm}$ (oostegites developed, weakly setose), $5.5 \mathrm{~mm}$ (oostegites developed, weakly setose), X40561/Cr-1478-FEFU, Abkhazia, Gagra Mountain Range, Arabika massif, speleological district "Treugol'nik", Troika cave 


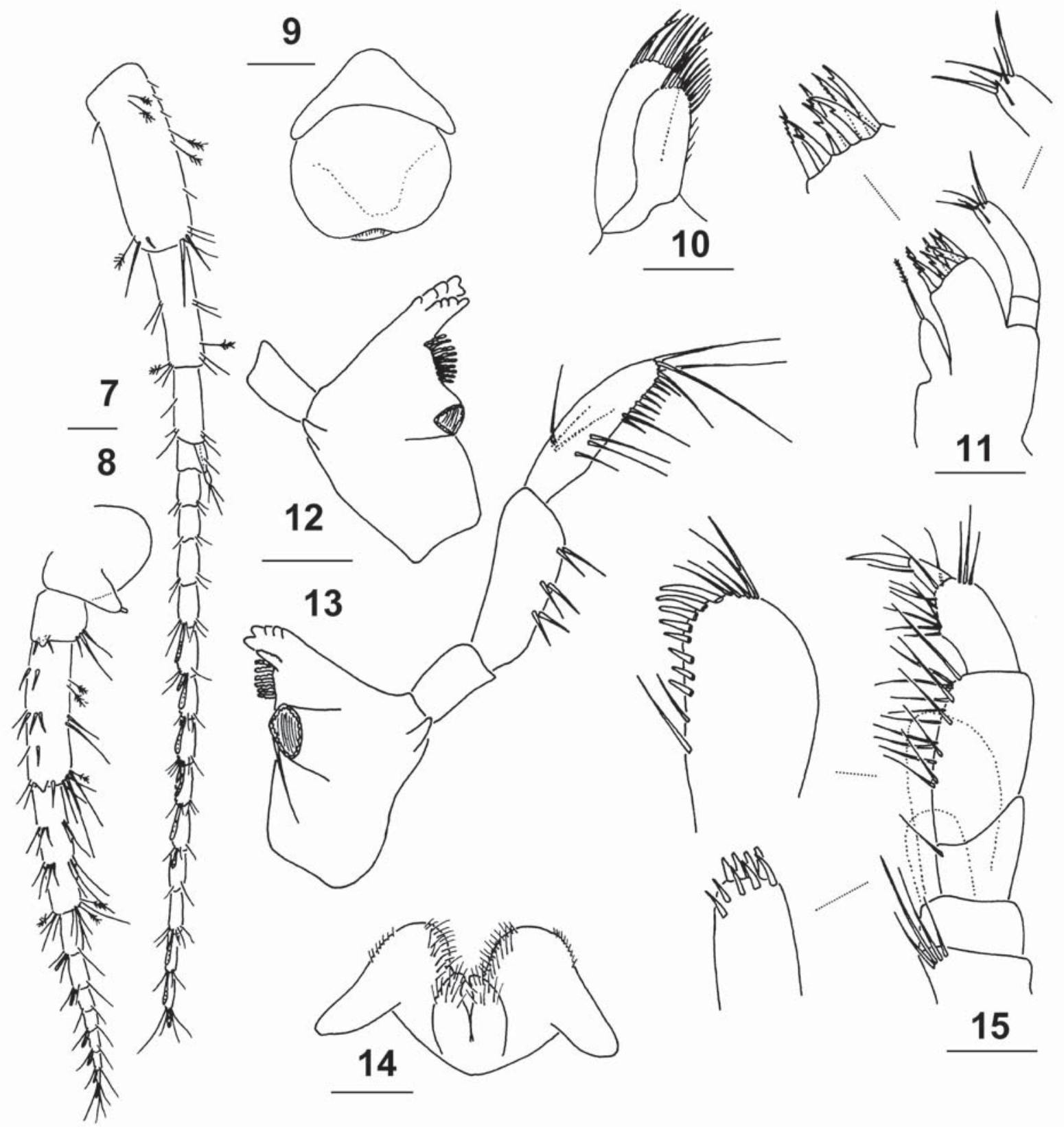

Figs 7-15. Niphargus inermis Birstein, 1940, female, $4.8 \mathrm{~mm}$, X40561/Cr-1478-FEFU, Troika cave: 7 - antenna 1; 8 - antenna 2; 9 - upper lip; 10 - maxilla 2; 11 - maxilla 1; 12 - mandible, left; 13 - mandible, right; 14 - lower lip; 15 - maxilliped. Scale bars $0.1 \mathrm{~mm}$.

Рис. 7-15. Niphargus inermis Birstein, 1940, самка, 4,8 мм, X40561/Cr-1478-FEFU, пещ. Тройка: 7 - антенна 1; 8 - антенна 2; 9 - верхняя губа; 10 — максилла 2; 11 - максилла $1 ; 12$ - мандибула, левая; 13 - мандибула, правая; 14 — нижняя губа; 15 ногочелюсть. Линейки 0.1 мм.

(cave 003), (approx., 43.383333, 40.366667), -30 $\mathrm{m}$ depth, cave pool, 27 Aug 2012, coll. E. Golubnichaya. 2 females $6.2 \mathrm{~mm}$ (oostegites developed, setose); 2 males $6.2 \mathrm{~mm}$ (without appendages); 2 juveniles $3.5 \mathrm{~mm}, 4.5 \mathrm{~mm}, 110 / 1 \mathrm{sd}-\mathrm{IBSS}$, Abkhazia, Gulripshi district, near Tsabal (Tsebelda), Nizhne-Shakuranskaya cave (43.029933, 41.3339), cave river, 13 Apr and 30 Jan 2012, coll. D. Palatov.

DESCRIPTION. Female, apparently submature [X40561/Cr-1478-FEFU, 4.8 mm]. General body morphology (Figs 2A, B, 16, 17, 22, 29, 32). Body length up to $5.5 \mathrm{~mm}$. Head length $7-8 \%$ of body length; rostrum indistinct. Pereonites $1-7$ and pleonites 1-3 with sparse thin setules. Epimeral plate 2: angle of postero-ventral corner approximately rectangular, obtuse; posterior margin concave; ventral margin convex; along ventral margin 2 stiff setae, along posterior margin 2 setae. Epimeral plate 3: angle of postero-ventral corner obtuse; posterior margin slightly concave; ventral margin convex; along ventral margin 2 stiff setae, along posterior margin 3 setae. Urosomite 1 postero- 


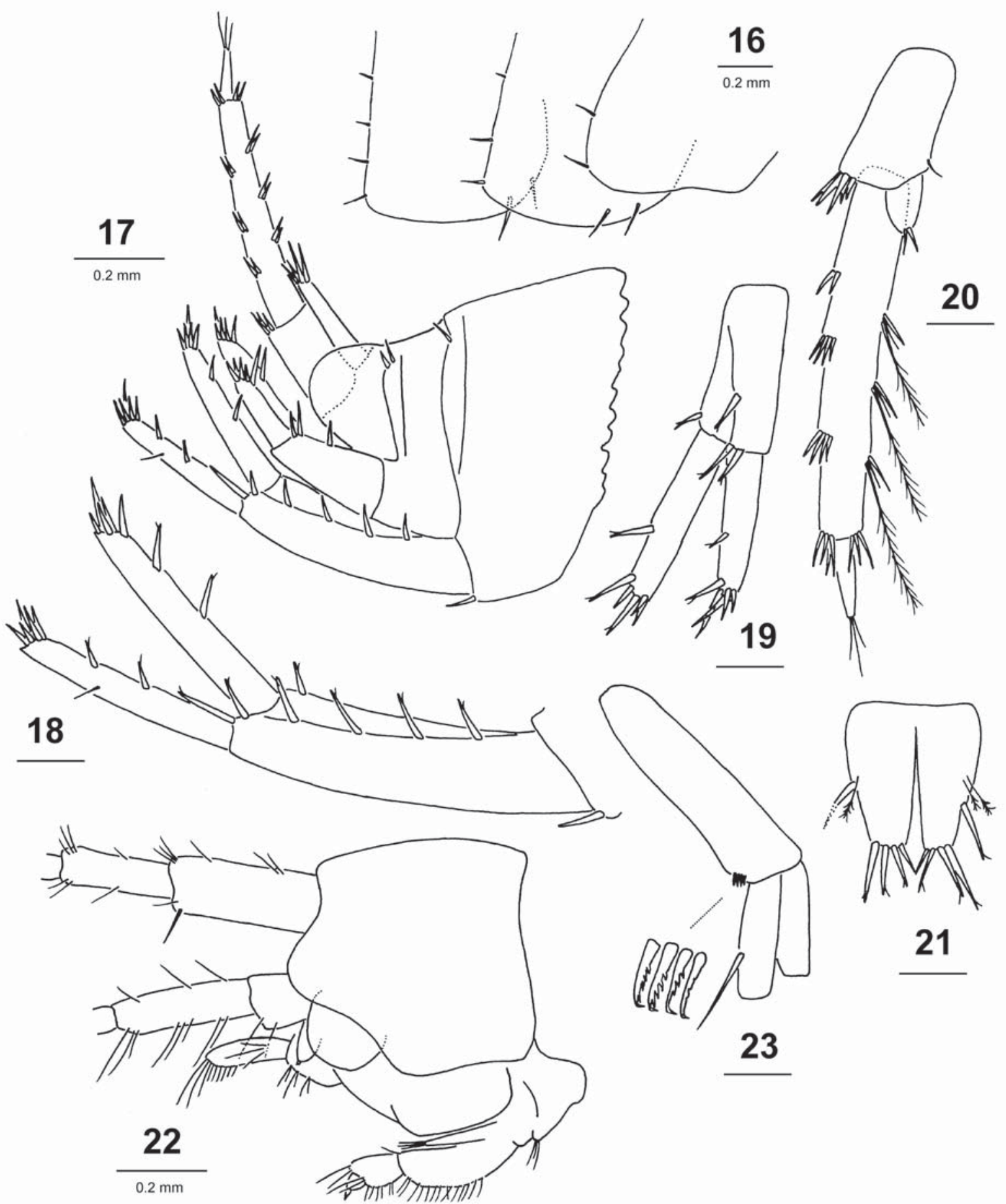

Figs 16-23. Niphargus inermis Birstein, 1940, female, 4.8 mm, X40561/Cr-1478-FEFU, Troika cave: 16 - epimeral plates 1-3; 17 - urosome; 18 - uropod 1; 19 - uropod 2; 20 - uropod 3; 21 - telson; 22 - cephalon; 23 - pleopod 3, part. Scale bars $0.1 \mathrm{~mm}$, if not indicated otherwise.

Рис. 16-23. Niphargus inermis Birstein, 1940, самка, 4,8 мм, X40561/Cr-1478-FEFU, пещ. Тройка: 16 - эпимеры 1-3; 17 уросома; 18 - уропод $1 ; 19$ - уропод $2 ; 20$ - уропод $3 ; 21$ - тельсон; 22 - голова; 23 - плеопод 3 , часть. Линейки 0,1 мм, если не указано иначе.

dorso-laterally with 2 spines; urosomite 2 postero-dorso-laterally with 4 spines; urosomite 3 postero-dorsolaterally anarmed (both sides together). At the base of uropod 1 single spine. Telson length: width ratio is 1 :
0.83 ; cleft 0.9 of length; only 4 apical spines per lobe present, these are $0.4-0.5$ of telson length; strong spines inserted laterally, in the middle part of telson each accompanied with 1 or 2 plumose seta. Antennae (Figs 


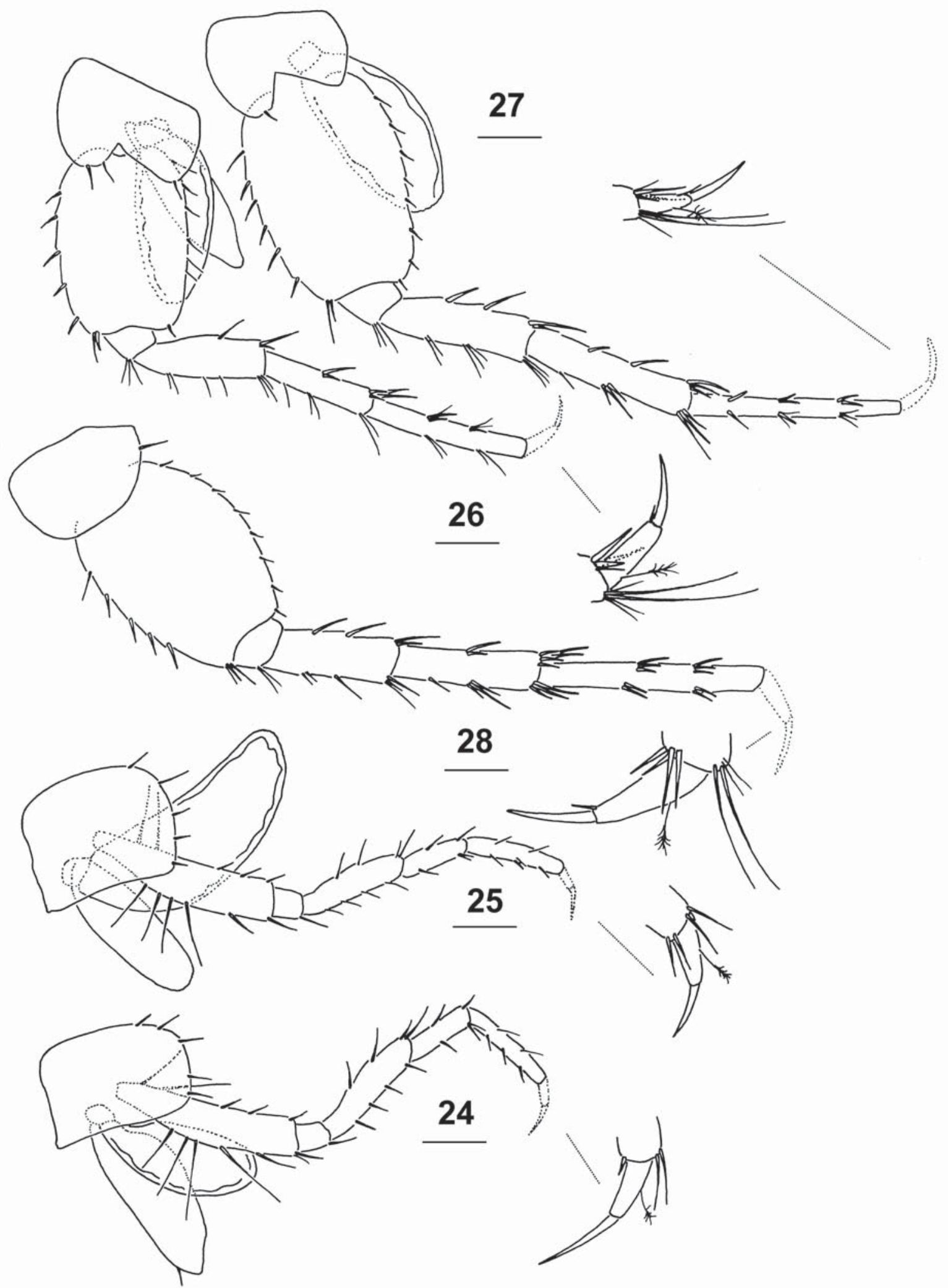

Figs 24-28. Niphargus inermis Birstein, 1940, female, $4.8 \mathrm{~mm}$, X40561/Cr-1478-FEFU, Troika cave: 24 — pereopod 3; 25 pereopod 4; 26 - pereopod 5;27 - pereopod 6;28 - pereopod 7. Scale bars $0.2 \mathrm{~mm}$.

Рис. 24-28. Niphargus inermis Birstein, 1940, самка, 4,8 мм, X40561/Cr-1478-FEFU, пещ. Тройка: 24 - переопод 3; 25 переопод 4; 26 - переопод 5; 27 - переопод 6; 28 - переопод 7. Линейки 0.2 мм. 
2A, B, 7, 8, 22, 31). Antenna $10.4-0.45$ of body length; flagellum with up to 15 articles; each article with 1-2 aesthetascs; peduncle articles in ratio $1: 0.6$ : 0.4 ; proximal article of peduncle dorso-distally unproduced; accessory flagellum bi-articulated; distal article shorter than half of proximal article length. Length ratio antenna $1: 2$ as $1: 0.6-0.65$; flagellum of antenna 2 with 8 articles, each article with 1 aesthetasc; peduncle articles lengths $4: 5$ is $1: 0.9$; flagellum 0.6 of peduncle length (articles 4+5); peduncular article 4 of antenna 2 with short stiff setae dorso-laterally; articles 4 and 5 with sets of long setae ventro-proximally. Mouth parts, typical niphargid (Figs 9-15, 22, 29, 30). Labrum rounded, clypeus detached, broader than long. Inner lobes of labium longer than half of the outer lobes. Left mandible: incisor with 5 teeth, lacinia mobilis with 4 teeth; between lacinia and molar row of 9 serrated spines. Right mandible: incisor process with 5 teeth, lacinia mobilis with several small denticles, between lacinia and molar a row of 6 serrated spines; molar process with a long naked seta. Mandibular palp article 2 as long as article 3 (distal); proximal palp article without setae; the second article with 6 setae grouped two by two; distal article with 1 A group of 3 setae, 3 B setae, 1 C seta, 7 D setae, 4 E setae. Maxilla 1 distal palp article with 6 apical and sub-apical setae; outer lobe with 7 bi- or pluri-toothed spines; inner lobe with 1 plumose setae. Maxilla 2 inner lobe smaller than outer lobe; both of them apically setose. Maxilliped palp article 2 with 14 setae along inner margin; article 4 (distal) with dorsal seta, bearing 1 seta at the nail base, nail longer than pedestal; outer lobe with 8 flattened spines and 5 long naked setae on apex; inner lobe with 4 flattened apical spines and 5 strong simple subapical spines. Coxal plates, gills (Figs 3, 4, 24-28). Coxal plate 1 of rhomboid shape, antero-ventral corner rounded; anterior and ventral margin of coxa 1 with 6 setae. Coxal plate 2 width : depth is 0.6 : 1 ; anterior and ventral margin with 6 setae. Coxal plate 3 width : depth is $0.7: 1$; along antero-ventral margin 5 setae. Coxal plate 4 width : depth is 0.75 : 1 ; posteriorly slightly concave (0.1-0.2 of coxa width); along anteroventral margin 5 setae. Coxal plates 5-6: only anterior lobe developed; posterior margin with 1 seta or unarmored. Coxal plate 7 semicircular, along posterior margin 1 seta. Coxal gills 2-6 large (exceeding distal tip of corresponding basipodit), saccular, irregularly ovoid. Gnathopod 1 (Figs 3, 5). Ischium with postero-distal set of setae. Carpus 0.5 of basis length and 0.8 of propodus length; anterior margin of carpus with the distal group of setae; carpus posteriorly with transverse rows of setae proximally, a row of lateral setae and row of submarginal setae. Propodus sub-quadrate, palm short, convex as long as posterior margin; along posterior margin 4 sets of denticulated setae; anterior margin with 1 couple of setae, antero-distal group with 6 setae; palmar margin with a rows of setae along outer face and short setae on inner face; defining angle with one strong corner S-spine accompanied laterally by 2 serrate L-spines on outer side, single supporting R- spine on inner face; nail long, 0.45 of total dactylus length, along anterior margin 1 seta, 4 short setae along inner margin present. Gnathopod 2 (Figs 4, 6). Basis width : length is $0.3: 1$. Ischium with 1 couple of postero-distal setae. Carpus 0.4 of basis length and 0.7 of propodus length; anterior margin of carpus with 1 distal seta; carpus posteriorly with transverse rows of setae proximally, a row of lateral setae and row of submarginal setae. Propodus small (compared to the body) and $1.5 x$ larger than propodus of gnathopod 1; propodus sub-quadrate, palm short, convex as long as posterior margin; posterior margin with 6-7 rows of denticulated setae; anterior margin with 1 seta; anterodistal group with 4 setae; palmar margin with a row of setae along outer face and short setae on inner face; defining angle with one strong corner S-spine accompanied laterally by 2 serrate L-spines on outer side, single supporting R-spine on inner face; nail long, 0.4 of total dactylus length, along anterior margin 1 seta, 4 short setae along inner margin present. Pereopods 3-4 (Figs 24, 25). Lengths of pereopods 3-4 equal. Dactylus 40.5 of propodus 4; nail length 0.5 of total dactylus length. Dactyli 3-4 with dorsal plumose seta; base of nail without a seta. Pereopods 5-7 (Figs 26-28). Lengths of pereopods $5: 6: 7$ is $1: 1.25: 1.19$. Pereopod 7 length 0.5 of body length. Bases 5-7 oblong, length : width is $1: 0.7-0.75$; posterior margin convex, without distal lobes; posteriorly 7-8 small spines and/or setae; anteriorly 5-6 spines and/or setae. Dactylus 7 length 0.45 of propodus 7 length. Dactyli 5-7 with dorsal plumose seta; at the base of nail weak seta. Pleopods and uropods (Figs 2A, B, 17-20, 23). Pleopods 1-3 each with 4-hooked retinacles. Pleopods 1-3 rami of 7-8 articles each. Uropod 1 protopodit with 6 dorso-lateral spines, 1 dorso-medial spines; exopodite : endopodite length is $0.9: 1$; rami straight with single spines and setae along inner and outer margins; endopodite with 2 spines, apically 5 spines; exopodite with 2 spines and 1 seta, apically 5 spines. Uropod 2 exopodite : endopodite length is $0.8: 1$. Uropod 30.2 of body length; protopodite with 1 small lateral seta and 5 apical spines; endopodite 0.3 of protopodite length, apically with 2 spines; exopodite rodshaped, distal article 0.2 of proximal article length, proximal article with 8 sets of setae, plumose setae along inner margin, distal article with 3 setae apically.

SEXUAL DIMORPHISM. Males slightly smaller than females but additional phenotypic features indistinct.

VARIABILITY. Unknown. Morphological variability of gnathopods (otherwise indistinguishable) was observed based on second female specimen $5.5 \mathrm{~mm}$ from Troika cave. Gnathopod 1: propodus of gnathopod 1 trapeziform, slightly longer than broad (ratio: 1 : 0.9 ), along posterior margin with 4 groups of setae; palm slightly convex, inclined nearly $2 / 5$ of propoduslength, defined by one corner S-spine accompanied laterally by 3 slender L-spines and single facial Msetae; dactylus along outer margin with one median seta (Fig. 5). Gnathopod 2: propodus trapeziform, as 


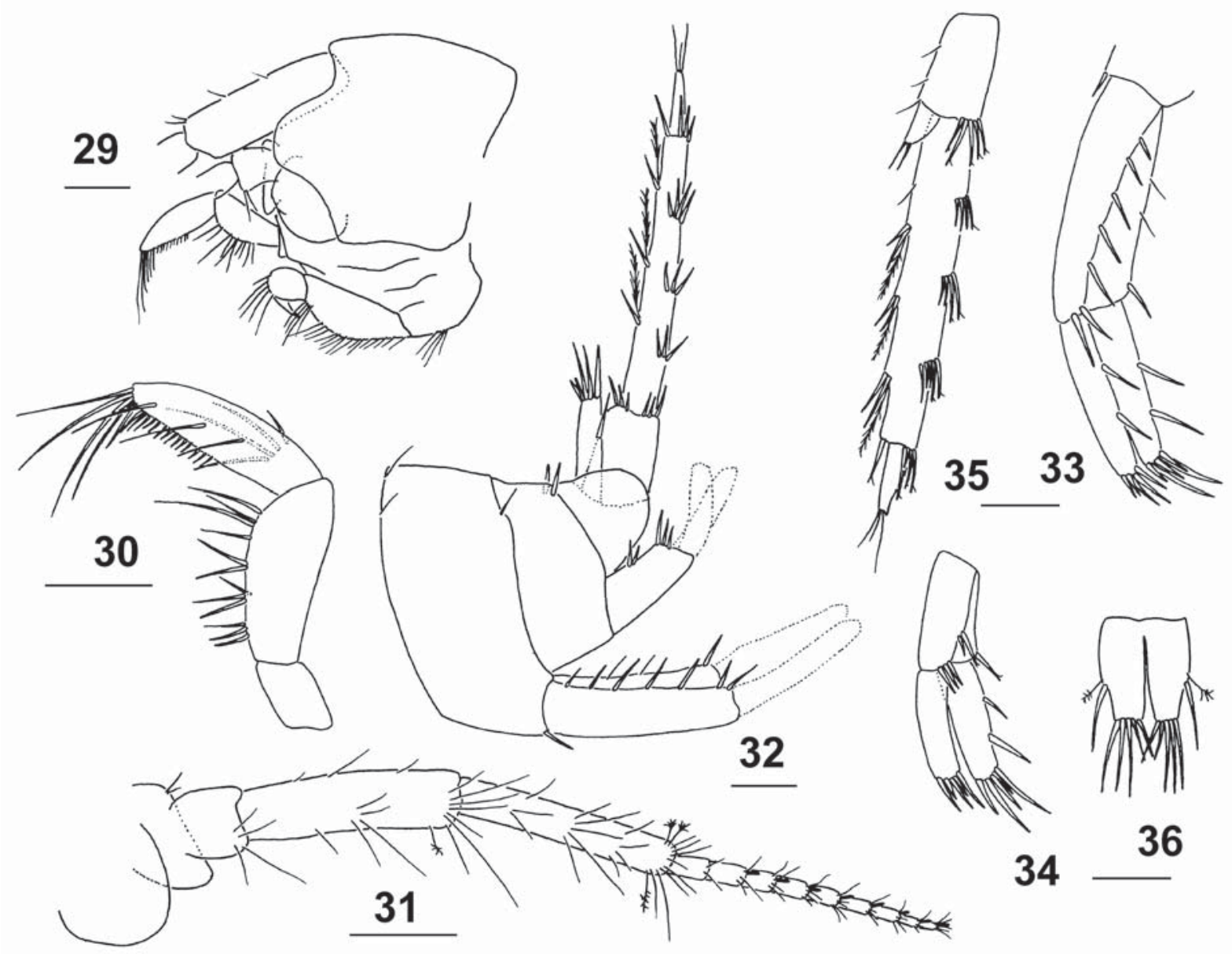

Figs 29-36. Niphargus inermis Birstein, 1940, female, 6.2 mm, 110/1sd-IBSS, Nizhne-Shakuranskaya cave: 29 — cephalon; 30 palp mandible; 31 - antenna 2; 32 - urosome; 33 - uropod 1; 34 - uropod 2; 35 - uropod 3; 36 - telson. Scale bars 0.2 mm.

Рис. 29-36. Niphargus inermis Birstein, 1940, самка, 6,2 мм, 110/1sd-IBSS, Нижне-Шакуранская пещ.: 29 - голова; 30 щупик мандибулы; 31 - антенна 2; 32 - уросома; 33 - уропод $1 ; 34$ - уропод 2; 35 - уропод $3 ; 36$ - тельсон. Линейки 0,2 мм.

long as broad, along posterior margin with 7 groups of setae; palm slightly convex, defined on outer face by one corner S-spine accompanied laterally by 2 slender L-spines and single facial M-setae; dactylus along outer margin with one median seta (Fig. 6).

TAXONOMIC COMMENTS. Among all known species from Georgia (N. alasonius Derzhavin, 1945 , N. borutzkyi Birstein, 1933, N. glontii Behning, 1940, N. gurjanovae Birstein, 1941, N. talikadzei Ljovuschkin in Giljarov et al., 1974), one median seta on dactylus of gnathopods 1-2 is known only in $N$. glontii (loc. typ.: spring on Tskhra-Tskaro pass left of the road Bakuriani-Tabiskuri, Georgia), however this species differs remarkably from specimens of Troika and Nizhne-Shakuranskaya caves by narrow basipodits (article 2) of pereopods 5-7, by absence of lateral spines on lobes of telson, more inclined palm of propodus in gnathopods 1 and 2 .

Within the Abkhazian species (N. ablaskiri Birstein, 1940, N. magnus Birstein, 1940, N. iniochus Birstein, 1941, N. otharicus Birstein, 1952, N. derzhavini
Birstein, 1952, N. eugeniae Derzhavin, 1945), only N. ablaskiri have one outer median seta on dactylus of propodus in gnathopods 1-2. N. ablaskiri differs from our specimens by more oblique palm of propodites in gnathopods $1-2$, by elevated number of dorsolateral spines on urosomites $1-2$, and by presence of a small spine at inner margin of dactylus in pereopods 3-7.

The specimens of Troika Cave (females 4.8 and 5.5 $\mathrm{mm}$ with weakly setose oostegites) are very similar to Niphargus ablaskiri inermis Birstein, 1940 described from Nizhne-Shakuranskaya cave in various characters: shape of gnathopod 1 propodus; dactyli of gnathopods 1-2 with one median seta along outer margin; maxilla 1 inner plate with one seta; short distal article of uropod 3 of outer ramus; dactyli of pereopods 3 and 4 along inner margin without seta near basis of the nail; dactyli of pereopods 5-7 along inner margin with one seta near basis of the nail; outer margin of telson with one spine on each side.

The specimens from Troika cave differs from original description of $N$. inermis (female, $11.0 \mathrm{~mm}$ ) report- 

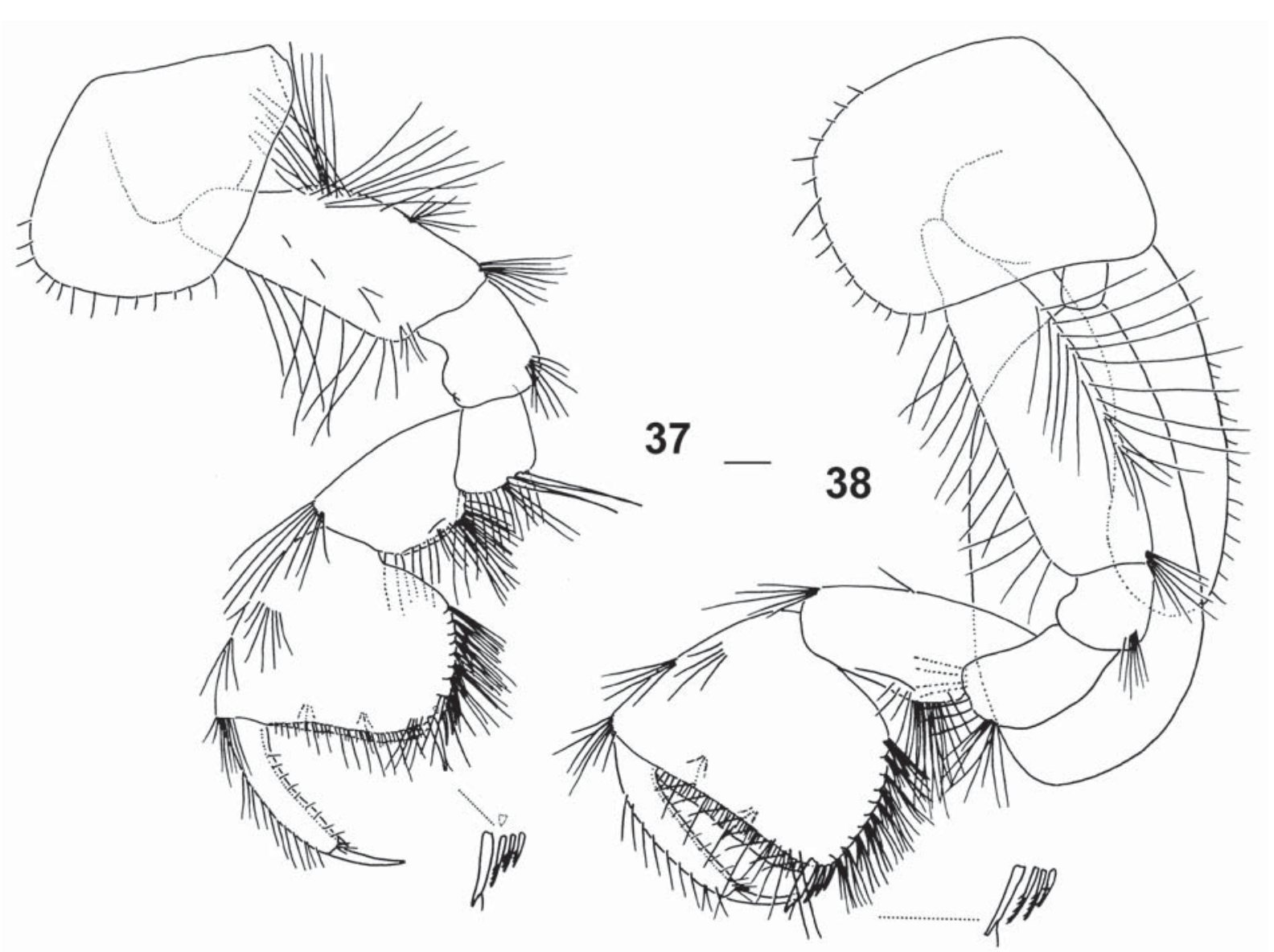

Figs 37-38. Niphargus iniochus Birstein, 1941, female, 12.0 mm, X40561/Cr-1479-FEFU: 37 — gnathopod 1; 38 — gnathopod 2. Scale bars $0.2 \mathrm{~mm}$.

Pис. 37-38. Niphargus iniochus Birstein, 1941, самка, 12,0 мм, X40561/Cr-1479-FEFU: 37 - гнатопод 1; 38 - гнатопод 2. Линейки 0,2 мм.

ed by Birstein [1940] in the shape of gnathopod 1 propodus - as long as broad, with strongly convex palm in $N$. inermis; but longer than broad, with only slightly convex palm in Troika cave; the shape of gnathopod 2 propodus — broader than long in $11.0 \mathrm{~mm}$ female of $N$. inermis and as long as broad in $5.5 \mathrm{~mm}$ female from Troika Cave. The differences from new collected specimens of $N$. inermis (female, $6.2 \mathrm{~mm}$ ) from type locality consists in interantennal lobe of head, setation of antenna 2 and uropod 2 (see Figs 2936). The distance between Troika and Nizhne-Shakuranskaya caves is about $90 \mathrm{~km}$ and several other species have settled the space between them (see Fig. 1). As the Birstein's original, our new specimens and Troika cave specimens are very similar, we can't exclude that the difference between them discussed above is ontogenic only, because our specimens are apparently submature and much smaller than the ones known as $N$. inermis from Tsebelda. For this reason, we consider the specimens from Troika cave as $N$. inermis Birstein, 1941 that evidently indicates a distinct population of this species at the Arabika massif.

DISTRIBUTION AND ECOLOGY. Besides locus typicus of $N$. inermis at Nizhne-Shakuranskaya cave the species known from Troika cave, Arabika massif (Fig. 1), where it occurs together with unidentified Typhlogammaridae. Oligochaeta Haplotaxis gordioides (Hartmann, 1821) were also collected from this same locality.

J.A. Birstein indicated fairly widespread distribution of $N$. inermis within Abkhazia. Besides locus typicus in Nizhne-Shakuranskaya cave it was recorded in two other Shakuranian and Tsebeldinskaya caves [Birstein, 1940], and in the Mikhailovskaja cave (43.078611, 41.016667) near Sukhumi [Birstein, 1952]. He also believed that an immature specimen Niphargus sp. sensu Birstein [1941] from "Golova Atapa" cave (approx. 42.92056, 41.55583) belonged to this species. However, some of these findings remain unproven and require confirmation.

Niphargus iniochus Birstein, 1941

Figs 2C, D, 37-64.

Niphargus puteanus iniochus Birstein, 1941: 263, fig. 4 (orig. descrip.). - Birstein, 1952: 32, 35. — Barnard, Barnard, 1983: 694.

Niphargus iniochus: Straškraba, 1972: 87 ("stygius-puteanus" group). — Karaman, 2012: 75. 


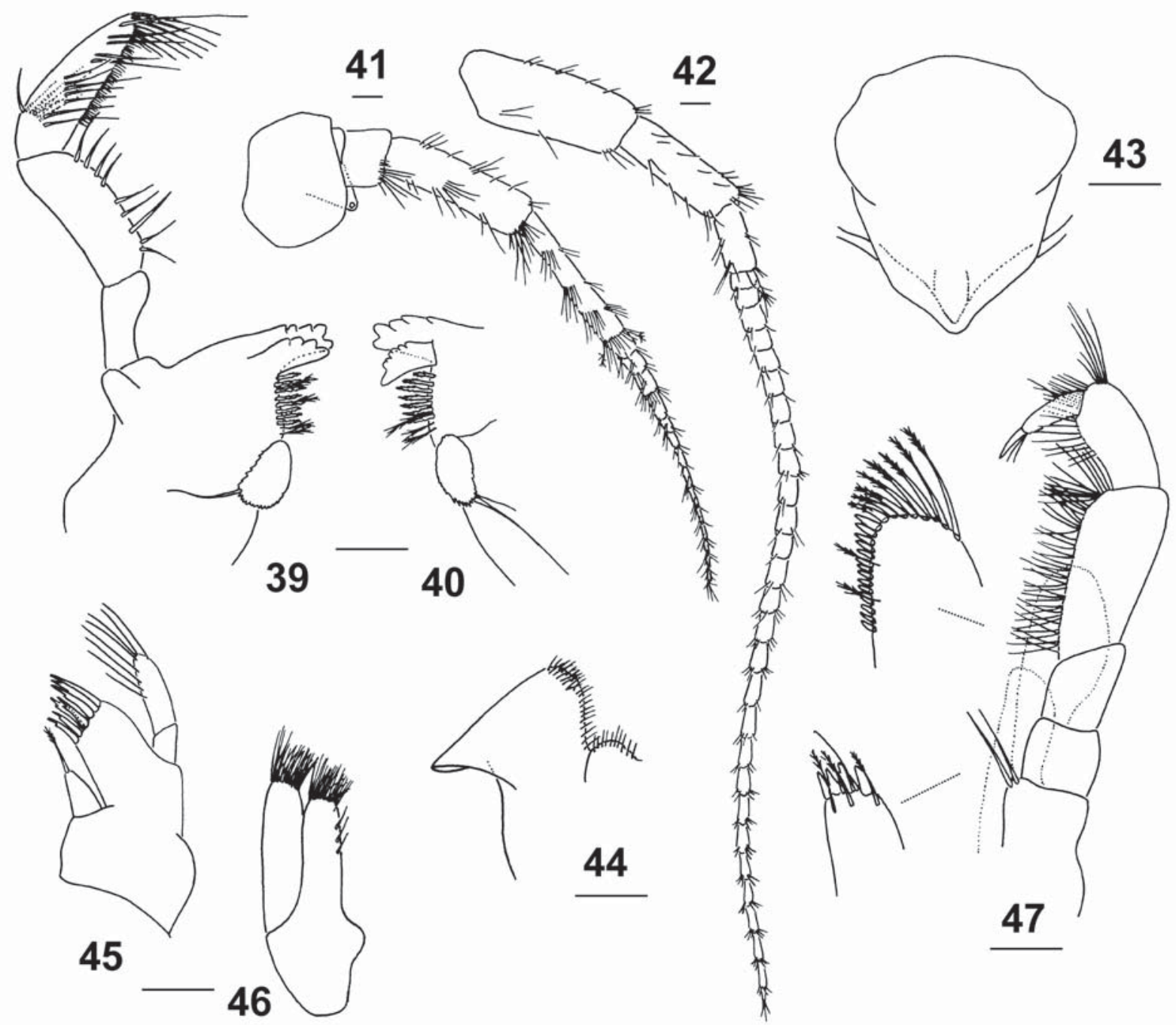

Figs 39-47. Niphargus iniochus Birstein, 1941, female, $12.0 \mathrm{~mm}$, X40561/Cr-1479-FEFU: 39 - mandible, left; 40 - mandible, right; 41 - antenna $2 ; 42$ - antenna $1 ; 43$ - upper lip; 44 - lower lip, part; 45 - maxilla 1; 46 - maxilla 2; 47 - maxilliped. Scale bars $0.2 \mathrm{~mm}$

Рис. 39-47. Niphargus iniochus Birstein, 1941, самка, 12,0 мм, X40561/Cr-1479-FEFU: 39 — мандибула, левая; 40 - мандибула, правая; 41 - антенна 2; 42 - антенна 1; 43 — верхняя губа; 44 — нижняя губа, часть; 45 — максилла 1; 46 — максилла 2; 47 ногочелюсть. Линейки 0,2 мм.

DIAGNOSIS (both sexes). Robust, large-sized specimens (sexual dimorphism marked, i.e., males distinctly larger than females, males dactyli 7 and uropodi sexually dimorphic). Antenna 1 short, reaching 50\% length of body; antenna 2 slender, reaching $65 \%$ length of antenna 1. Maxilla 1 inner plate with one plumose seta, outer plate with 7 spines (most of them bi-toothed). Mandibular palp article 3 with 1 A group of 6 setae, with $5 \mathrm{C}$ group of 12 setae, $42 \mathrm{D}$ setae, $9 \mathrm{E}$ setae. Gnathopods 1-2 relatively small, with propodus not larger than corresponding coxa; defining angles of both gnathopods with one strong corner S-spine accompanied laterally by 3 serrate L-spines on outer side, supporting R-spine on inner face absent; dactyli along outer margin with numerous setae, nails relatively long; inner margin of dactyli of pereopods 3 and 4 with 2 small spines (with 1 spine near basis of the nail); dactyli of pereopods 5-7 with 5 or 6 spines on inner margin. Urosomites 1-2 with dorsolateral groups of spines. Pleopods 1-3 with 2 retinacula each. Uropod 1 rami almost equal in female (inner ramus scarcely longer than outer one) but outer ramus twice shorter than inner in male; uropod 3 large (with allometricly elongated distal article in male); telson with distal and lateral spines, facial spines present. Coxal gills 2-6 large, sacci-forme. Oostegites $2-5$ moderate, setose with short stiff setae. Body length 5.5-12.0 mm (females), 17.0 (male).

MATERIAL EXAMINED. Female, $12.0 \mathrm{~mm}$ (oostegites developed, setose), male, $17.0 \mathrm{~mm}$, X40561/Cr-1479-FEFU, Abkhazia, Gulripshi district, near Tsabal (Tsebelda), Nizhne-Shakuranskaya cave $(43.029933,41.3339)$, cave river, 13 Apr and 30 Jan 2012, coll. D. Palatov. Additional specimens from the same site 


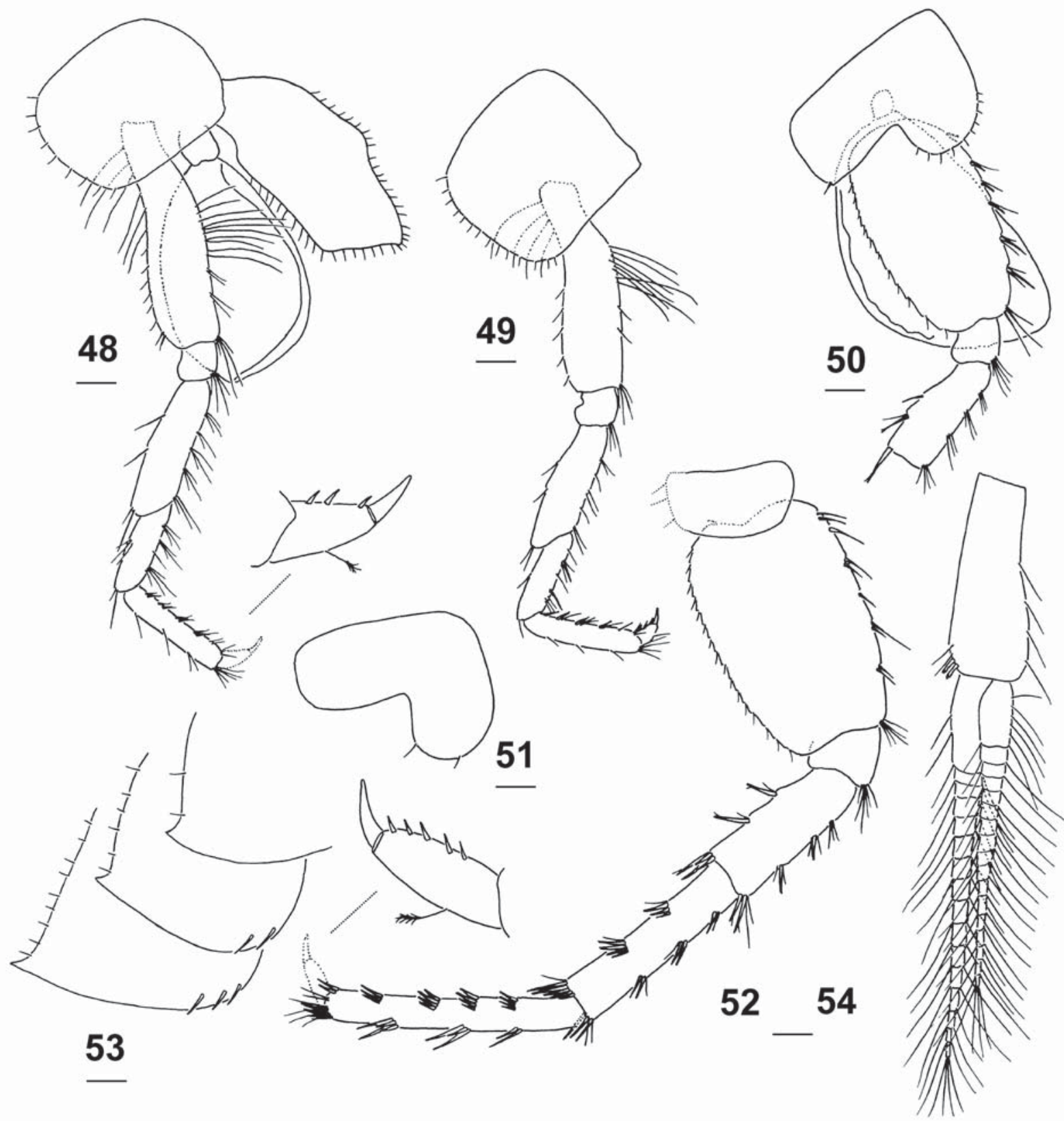

Figs 48-54. Niphargus iniochus Birstein, 1941, female, 12.0 mm, X40561/Cr-1479-FEFU: 48 — pereopod 3; 49 — pereopod 4; 50 pereopod 5, part; 51 - coxa 6;52 - pereopod 7; 53 - epimeral plates 1-3; 54 - pleopod 3. Scale bars $0.2 \mathrm{~mm}$.

Рис. 48-54. Niphargus iniochus Birstein, 1941, самка, 12,0 мм, X40561/Cr-1479-FEFU: 48 - переопод 3; 49 - переопод 4; 50 переопод 5 , часть; 51 - кокса $6 ; 52$ - переопод 7; 53 - эпимеры 1-3; 54 - плеопод 3. Линейки 0,2 мм.

were examined (all specimens measured, partially dissected and stored in vial 110/2sd-IBSS): male $17.0 \mathrm{~mm}$; female $6.75 \mathrm{~mm}$ (oostegites developed, non-setose); 2x females $5.5 \mathrm{~mm}$ (oostegites developed, non-setose).

DESCRIPTION. Female, [X40561/Cr-1479-FEFU, $12.0 \mathrm{~mm}$. General body morphology (Figs 2C, D, $53,55,56,60)$. Body length up to $17.0 \mathrm{~mm}$. Head length $8-11 \%$ of body length; rostrum blunt-pointed. Pereonites 1-7 and pleonites 1-3 with sparse setae. Epimeral plate 2: angle of postero-ventral corner tapered, acute; posterior margin convex; ventral margin convex; along ventral margin 2 weak spines, along posterior margin 6 setae. Epimeral plate 3: angle of postero-ventral corner acute; posterior margin straight; ventral margin convex; along ventral margin 3 weak spines, along posterior margin 9 setae. Urosomite 1 postero-dorso-laterally with 2 spines accompanied with setae; urosomite 2 postero-dorso-laterally with 2 groups of 4 spines accompanied with setae; urosomite 3 postero-dorso-laterally anarmed (both sides together). At the base of uropod 1 single spine. Telson length : width ratio is $1: 1$; cleft about 0.6 of length; only 3 apical 


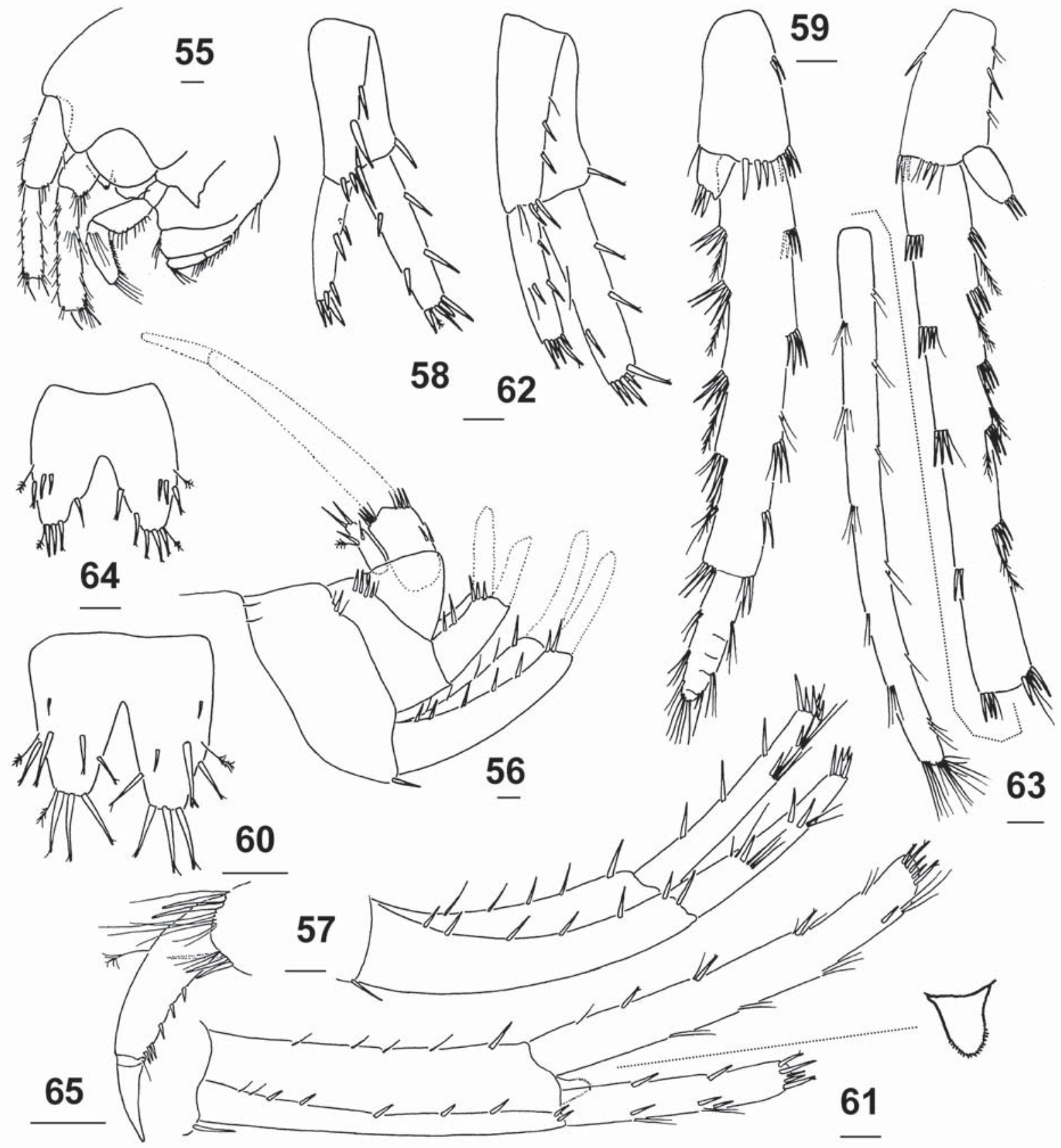

Figs 55-65. Niphargus iniochus Birstein, 1941, female, $12.0 \mathrm{~mm}$, X40561/Cr-1479-FEFU: 55 — cephalon; 56 — urosome; 57 — uropod 1; 58 - uropod 2; 59 - uropod 3; 60 - telson. Male, $17.0 \mathrm{~mm}$, X40561/Cr-1479-FEFU: $61-$ uropod 1; $62-\operatorname{uropod} 2 ; 63-$ uropod 3; 64 - telson; 65 - pereopod 7 dactylus. Scale bars $0.2 \mathrm{~mm}$

Рис. 55-65. Niphargus iniochus Birstein, 1941, самка, 12,0 мм, X40561/Cr-1479-FEFU: 55 — голова; 56 - уросома; 57 уропод 1; 58 - уропод 2; 59 - уропод $3 ; 60$ - тельсон. Самец, 17,0 мм, X40561/Cr-1479-FEFU: 61 — уропод 1; 62 — уропод 2; 63 - уропод $3 ; 64$ - тельсон; 65 - дактилюс переопода 7. Линейки 0,2 мм.

spines per lobe present, these are $0.3-0.35$ of telson length; strong spines inserted laterally, in the middle part of telson each accompanied with 1 plumose seta; 2 facial and 1 inter-medial spines per lobe present. Antennae (Figs 2C, D, 41, 42, 55). Antenna 10.5 of body length; flagellum with up to 29 articles; peduncle articles in ratio $1: 0.75: 0.4$; proximal article of peduncle dorso-distally unproduced; accessory flagellum bi-articulated; distal article shorter than half of proximal article length. Length ratio antenna $1: 2$ as $1: 0.65$; flagellum of antenna 2 with 15 articles; peduncle article 4 as long as article 5; flagellum 0.9 of peduncle length (articles 4+5); peduncular articles 4 and 5 with sets of short setae. Mouth parts well developed (Figs 
39-47). Labrum entire, trapezoid, slightly longer than broad. Inner lobes of labium as long as outer lobes. Left mandible: incisor with 5 teeth, lacinia mobilis with 4 teeth; between lacinia and molar row of 8 serrated spines. Right mandible: incisor process with 5 teeth, lacinia mobilis broad with several denticles, between lacinia and molar a row of 7 serrated spines; molar process with a long naked seta. Mandibular palp article 2 slightly shorter then article 3 (distal); proximal palp article without setae; the second article with 9 setae; distal article with 1 A group of 6 setae, with 5 B group of 12 setae, $42 \mathrm{D}$ setae, 9 E setae. Maxilla 1 distal palp article with 8 long apical and sub-apical setae; outer lobe with 7 bi-toothed or toothless spines; inner lobe with 1 plumose setae. Maxilla 2 inner lobe smaller than outer lobe; both of them narrow and apically setose. Maxilliped palp article 2 with 48 setae along inner margin; article 4 (distal) with dorsal seta, bearing 2 setae at the nail base, nail one half of the pedestal; outer lobe with 15 flattened strong spines laterally and 8 pappose setae sub- and apically; inner lobe with 4 flattened apical spines accompanied with 4 setae. Coxal plates, gills (Figs 37, 38, 48-52). Coxal plate 1 sub-rhomboid, antero-ventral corner rounded; anterior and ventral margin densely setose. Coxal plate 2 width : depth is $0.7: 1$; anterior and ventral margin densely setose. Coxal plate 3 width : depth is $0.7: 1$; along antero-ventral margin 9 setae. Coxal plate 4 width : depth is 0.9 : 1 ; posteriorly slightly concave; along antero-ventral margin densely setose. Coxal plates $5-$ 6: only anterior lobe developed; posterior margin with 1 seta or naked. Coxal plate 7 semicircular, posterior margin with 3 setae. Coxal gills 2-6 large (exceeding distal tip of corresponding basipodit), saccular, irregularly ovoid. Gnathopod 1 (Fig. 37). Ischium with postero-distal set of thin setae. Carpus 0.5 of basis length and 0.7 of propodus length; anterior margin of carpus with the distal group of setae; carpus posteriorly densely setose. Propodus sub-rectangular, palm straight, longer than posterior margin; along posterior margin 8 sets of setae; anterior margin with 2 sets of setae, anterodistal group with 8 setae; palmar margin with 2 rows of short setae along outer and inner face accompanied with sparse long setae; defining angle with 1 strong corner S-spine accompanied laterally by 3 serrate Lspines on outer side, single supporting R-spine on inner face; nail long, 0.39 of total dactylus length, along anterior and inner margins numerous setae. Gnathopod 2 (Fig. 38). Basis width : length is $0.36: 1$. Ischium with set of thin setae. Carpus 0.5 of basis length and as long as propodus; anterior margin of carpus with 1 distal set of setae and 1 seta on medial face; carpus posteriorly densely setose. Propodus small (compared to the body) and slightly broader than propodus of gnathopod 1; propodus sub-rectangular, palm straight, longer than posterior margin; posterior margin with 10 sets of setae; anterior margin with 2 sets of setae; antero-distal group with 7 setae; palmar margin with 2 rows of short setae along outer and inner face accompanied with sparse long setae; defining angle with 1 strong corner S-spine accompanied laterally by 3 serrate L-spines on outer side, supporting $\mathrm{R}$-spine on inner face absent; nail long, 0.28 of total dactylus length, along anterior and inner margins numerous setae. Pereopods 3-4 (Figs 48, 49). Lengths of pereopods 3-4 sub-equal. Dactylus 40.3 of propodus 4 ; nail length 0.3 of total dactylus length. Dactyli 3-4 with dorsal plumose seta and 3 spines ventrally. Pereopods 5-7 (Figs 50-52). Pereopod 7 length 0.4 of body length. Bases 5-7 oblong, length : width is 1 : 0.6-0.65; posterior margin convex, without distal lobes; posteriorly small numerous setae; anteriorly 6 sets of 2-3 setae. Dactylus 7 length 0.36 of propodus 7 length, with dorsal plumose seta; inner margin with 5 small spines. Pleopods and uropods (Figs 2C, D, 54, 57-60). Pleopods 1-3 each with 2-hooked retinacles. Pleopods 1-3 peduncles with long setae on outer face; rami of 16-17 articles each. Uropod 1 protopodit with 7 dorso-lateral spines, 5 dorso-medial spines; exopodite : endopodite length is $0.8: 1$; rami slightly curved with groups of spines and setae along inner and outer margins, with 5 spines apically. Uropod 2 exopodite : endopodite length is 0.7 : 1 ; endopodite broad and compressed. Uropod 3 0.2 of body length; protopodite with 2 small lateral spines and 7 apical spines; endopodite vestigial, 0.3 of protopodite length, apically with 3 spines; exopodite rod-shaped, distinctly curved, distal article 0.3 of proximal article length, proximal article with 11 sets of spines accompanied with simple and plumose setae along inner margin, distal article with sets of setae.

SEXUAL DIMORPHISM. Males are larger than females; dactyli 7 with 6 short spines (3 of them in group near nail) on inner margin (Fig. 65); male uropod 1 and 2 with broad, compressed rami; uropod 1 exopodite twice shorter than endopodite, protopodit bearing distal marginally serrate process; uropod 3 with extra-large distal article furnished with 13 sets of thin setae (see Figs 61-64).

VARIABILITY. Not observed.

TAXONOMIC COMMENTS. The comparison with known Abkhazian species and with the original description of this species [see Birstein, 1941: 263] left no doubt that our samples from the Nizhne-Shakuranskaya cave belong to $N$. iniochus. However, I was not able to distinguish this species from the previously described Niphargus longicaudatus magnus Birstein, 1940 inhabits closely located "Golova Atapa" cave. It seems interesting, that indicating distribution of N. magnus in Abkhazia Birstein [1940] additionally reported about collection of this species from the Sredne-Shakuranskaya cave near Tsebelda and in the nameless cave in Tsebelda. It is possible that $N$. iniochus is a junior synonym of $N$. magnus but poor description of the latter does not allow to assert it confidently.

DISTRIBUTION AND ECOLOGY. The species $N$. iniochus to the moment known, besides locus typicus at small cave near Apra (Andreevka) [43.116944, 41.0211], from Nizhne-Shakuranskaya cave (Fig. 1) where it occurs together with $N$. inermis and Zenkevitchia admirabilis. 
ACKNOWLEDGEMENTS. I am thankful to Pavel Rudko (Siberian Federal University, Krasnoyarsk), Elena Golubnichaya (Far Eastern Federal University, Vladivostok) and Dmitry Palatov (Lomonosov Moscow State University) for providing me with materials from several caves and information on geographic distribution of Niphargus species in Abkhazia, to Prof. V.P. Semernoy (Yaroslavl State University) for identification of Oligochaeta, Prof. G.S. Karaman (Montenegrin Academy of Sciences and Arts, Podgorica) offered many helpful comments on an early draft of the manuscript, and last but not least I would like to thank Dr. Cene Fišer (University of Ljubljana) for reviewing and to Dr. Yana Olefir (School of Regional and International Studies FEFU, Vladivostok) for correcting the English.

\section{References}

Barnard J.L., Barnard C.M. 1983. Freshwater Amphipoda of the World. Vol. 1, 2. Mt. Vernon, Virginia: Hayfield Associates. $830 \mathrm{pp}$.

Birstein J.A. 1940. [Biospeologica Sovietica 3. Ueber die Fauna der Höhlen Amphipoden Abchasiens] // Bull. Moskovsk. Obs. Ispytatelei Prirody. Otd. biol. Vol.49. P.47-55 [in Russian, with German summary].

Birstein J.A. 1941. [The subterranean amphipods of Abkhasia with notes on the Niphargus-species of Transcaucasus] // Sbornik trudov Zool. Muz. Moskovsk. Gosud. Univ. Vol.6. P.259-272 [in Russian, with English summary].

Birstein J.A. 1952. [Biospeologica Sovietica 12. Subterranean amphipods of the region Khosta - Gudauta (Western Transcaucasia)] // Bull. Mosk. Obs. Ispitat. Prirod. Otd. biol. Vol.57. P.26-39. [in Russian].

Bonfield J.K., Smith K.F., Staden R. 1995. A new DNA sequence assembly program // Nucleic Acids Res. Vol.24. P.4992-4999.
Derzhavin A.N. 1945. [The subterranean Amphipoda of Transcaucasus] // Trudy AN Azerb. SSR. Baku. Vol.8. P.27-43 [in Russian, with English summary].

Folmer O., Black M., Hoeh R., Lutz R., Vrijenhoek R. 1994. DNA primers for amplification of mitochondrial cytochrome c oxidase subunit I from diverse metazoan invertebrates // Mol. Mar. Biol. Biotechnol. Vol.3. P.294-299.

Giljarov M.S., Lagidze O.I., Levuskin S.I., Talikadze D.A. 1974. [First species of soil dwelling amphipod of the genus Niphargus (Amphipoda, Crustacea)] // Dokl. Akad. Nauk SSR. Ser. biol.Vol.217. P.1449-1452 [in Russian].

Gorodkov K.B. 1961. [The simplest microprojector for drawing insects] // Entomol. Obozr. Vol.40. P.936-939 [in Russian, with English summary].

Holsinger J.R. 1974. Systematics of the subterranean amphipod genus Stygobromus (Gammaridae). Part I: Species of the western United States // Smithsonian Contrib. Zool. Vol.160. P.1-63.

Karaman G. 1969. XXII Beitrag zur Kenntnis der Amphpoden. Über einige neue Formen des Genus Sarothrogammarus (Gammaridae) aus Afghanistan // Acta Mus. Macedon. Scientiar. Natur., Skopje. Vol.11. P.195-208.

Karaman G.S. 2012. New species of the subterranean genus Niphargus Schiödte, 1849 (Amphipoda, Gammaridea, Niphargidae) from Russia, N. krasnodarus sp. n. (Contribution to knowledge of Amphipoda 256) // Biol. Serbica. Vol.34. P.75-88.

Skalski A.W. 1980. The variability and systematic position of three species of Niphargus from the Caucasus // Crustaceana. Suppl. Vol.6. P.38-43.

Straškraba M. 1972. Les groupements des especes du genre Niphargus (sensu lato) // Mus. Civ. Stor. Natur., Mem. Fuori Ser. Verona. P.85-90.

Voronov Yu.N. 1969. [Archaeological map of Abkhazia]. Suhumi:" Alašara. 88 pp. [in Russian]

Zaitsev F.A. 1948. [Review of cave fauna of Georgia] // Tr. Zool. Inst. GSSR. Vol.8. P.151-173 [in Russian].

Responsible editor K.G. Mikhailov 